\title{
The Voice of the People Compromised and Accountability Denied
}

\author{
Tassew Shiferaw Gizaw (Ph.D.) \\ Grand Canyon University, USA
}

Received: Sep. 28, 2017 Accepted: Oct. 16, 2017 Online published: Oct. 25, 2017

doi:10.5296/jpag.v7i4.12058 URL: https://doi.org/10.5296/ jpag.v7i4.12058

\begin{abstract}
The study examines the impact of determinants of democratic governance on political rights and public policy in the sub-Saharan African countries. The study follows the quantitative research tradition using a linear regression model. Together with one trend variable, seven independent variables representing determinants of governance, as well as one dependent variable (political rights/the voice of the people), have been applied into the equation. The computation yielded statistical results that could guide meaningful analysis about the theme under study. The study shows that the lack of democratic governance has negatively affected the status of political rights, and human rights as well as accountability. Thus, the voice of the people in matters that influence public policy has been constrained in the 32 sub-Saharan African countries.
\end{abstract}

Keywords: governance, political rights, public policy, human rights, accountability

\section{Introduction}

Even though the literature presents the discourse of democratic governance following different approaches, their varying perspectives converge towards a need of promoting the rule that addresses the demands of citizens. According to prominent scholars, for instance, Bevir (2010); Clawson and Oxley (2013); Morlino (2012); Walby (2009), the essence of democratic governance entails crucial areas such as political rights and the rule of law. This underscores political rights and voice in the choice of governmental administration affecting the day-to-day lives of citizens. Thus, it is about the right of citizens to have a say in any ruling enterprise that affects their livelihood. Hence, democratic governance addresses fundamental elements, such as the rule of law, human, and political rights.

Political rights capitalize on fundamental freedoms that guide forces in the political arena towards the respect of citizens' choice without any undue restraints. "Political rights include the right to vote, to stand for office, to campaign, and to organize political parties (Diamond, 2016: p. 39)." Thus, the preservation of citizens' political rights demands that active political 
participation in voting or campaigning not be prohibited. According to Hislope and Mughan (2012), political activities, such as voting, entail conventional participation. On the other hand, unconventional political rights include activities such as peaceful demonstration, boycotting or signing petitions. In democratic societies, political rights are promoted, since citizens' involvement and opinions are desirable to influence the political process. It is because "...the opinions of ordinary individuals - whose bidding governments presume or are explicitly charged to pursue - can serve as a regular, requisite resource...to achieve the ends of equity, efficiency, responsiveness, and representation (Lee and Odugbemi, 2011, p. 419)." Accordingly, governments should be ready to monitor and evaluate their performance based on the feedback they receive from citizens. They serve the public and are under obligation to respond to the voice of the people by preserving political rights.

This study emphasizes that it is the primary duty of governments to follow adequate modes of governance that preserve political rights and increase the awareness level of citizens relative to the degree of political participation. The need for well-informed, politically active citizens is crucial for the advancement of society and sustainable development. The contemporary understanding of citizenship encompasses the importance of citizens being informed, and henceforth able to contribute positively to the community based on knowledge of the various issues. In so doing, it is possible to create political efficacy, which is the capability of citizens to influence the political process. It demands the tradition of active engagement in politics. "One important characteristic that participants tend to exhibit is a sense of efficacy, which is a sense that one's participation can make a difference (Green and Luehrmann, 2007, p.213)." It is essential, therefore, that people enjoy freedom of expression and the right to assemble, in order to convey their messages, demands and/or aspirations and thereby generate public opinion and, through such means, public policy. A free media also is indirectly responsible for promoting the exercise of political rights by directing the attention of the public towards some of the most pressing societal problems. It is when citizens enjoy their political rights that they can actively participate in the political process in order to influence policy formulation and the course of action towards achieving what they consider to be in their best interest. In other words, political rights warrant the capacity of citizens to participate in any public activity that affects their livelihood. The protection of political rights ensures that the voice of citizens is heard, which is the essence of democracy, because "[ [..] democracy is a set of rules and processes encompassing key features like competitive elections, a free press, multiple parties [...] (Hislope and Mughan, 2012, p.12)."

Thus, the study highlights the importance of political rights/the voice of the people. Two human rights instruments (an international as well as a regional) have been used as references to underline the obligation to protect human rights in relation to political rights. They are: The Universal Declaration of Human Rights (UDHR), and the African Charter on Human and Peoples' Rights (ACDEG). All the countries under study are signatories of these treaties. The theme is discussed considering the two human rights tools, as well as pertinent determinants of governance that affect political rights. When political rights are valued, the voice of citizens is appreciated, persuading public policy and warranting accountability. This circumstance matches the principles of human rights and democratic governance enshrined in 
the above indicated human rights instruments, which will be explained in the succeeding pages.

\section{Theoretical Framework}

It is important to reiterate that the voice of citizens can only be heard when they can express themselves and have a say in the political process. This demands how well governments work to address the public concern with maintaining democratic governance. Governance can also be referred to as a course of action, which rests upon the capacity and commitment of governments, based on their institutional mandate, to deal with the needs of citizens. Massey and Johnston (2015) note the notion of governance came into being because of the ever more complex relations between governments and the communities they serve. The essence of the concept reflects upon the extent to which citizens feel governmental entities protect the welfare of the public. Corresponding to his idea cited in the introduction section, Bevir (2010) points out that there are those international organizations, such as the World Bank, which are interested in good governance as part of their work with developing countries. In order to make some important decisions, these organizations endeavor to make sure that there are no concerns that contradict their values. Their values highlight principles, which "include [...] consistent laws, independent judiciary, and the place of codified law of concepts such as fairness, justice, and liberty....( p.99)". In line with this, as posted on its website, the World Bank describes governance as the capability of governments to design and execute sound policies to serve citizens through democratic order.

O'Neil and Share (2010) indicate that the protection of essential freedoms and rights is the basic feature of democratic regimes. These authors note authoritarian regimes prohibit basic rights by controlling " ... the role of the public in decision making and often deny citizens' basic rights and restrict their freedoms (p.6)." It can be contended that denying citizens basic rights may be tantamount to denying their very existence. Thus, Walby succinctly describes democratic governance as "a key component of good governance, which also involves the rule of law, [...] human rights, and those institutions sufficiently developed to deliver democratic intent (178)." In line with this description, Bevir identifies two major approaches to define governance. The first approach relates good governance to democracy and elections and the second one is concerned with human rights. In this study, which focuses on 32 sub-Saharan African countries where data could be obtained relevant to the topic of investigation, both approaches have been adopted, and, therefore, "good governance simply means democratic and competitive elections and the lines of accountability that are thus established (Bevir, 2010, p.98)." This leads towards a respect for the voice of the people that enhances their ability to influence public policy as well as the bestowal of any benefits that the rights of citizenship should as a matter of course entail.

In order to highlight the vital importance of serving the people, the World Bank postulates certain governance dimensions (indicators), which play a significant role to promote political rights, and thus democratic governance. They are: "voice and accountability, political stability and absence of violence, government effectiveness, regulatory quality, rule of law, and control of corruption (Accessed on July 23, 2016)." Since these indicators are adequate 
and they are found to be highly suitable, they have been adopted in this study. In order to observe the economic impact, per capita GDP and unemployment rates have been included. These determinants of governance reflect perceptions associated with how well governmental functions should operate in compliance with the voice of the people. Simply put, governance entails several factors including the capacity and commitment of governments, based on their institutional mandate, to promote the political rights of citizens on a sustainable basis. Thus, in this study, democratic governance is about the identified determinants serving the target dimension-the people's voice--(voice and accountability). It has been further explained in the succeeding pages.

To ensure clarity, adopting the World Bank's description, the voice and accountability dimension is about citizen's ability to choose their government. It includes basic freedoms such as the right to have a say, and to collectively express themselves in association. Their access to enjoy free media is also categorized under this dimension. Essentially, the voice of the people outweighs any governmental decision; no policy should exist in contravention with the people's preference. The crux of the matter is that the voice of the people matters and thus, governments are accountable to the people they serve. The second-dimension focusses on the level of political stability or the nonexistence of violence. The voice of the people could be better entertained with political stability and peaceful coexistence. In fact, it is important to acknowledge that there cannot be complete political stability or absolute peace in society. It is a common knowledge that when there would be different interests involved, conflict can inevitably emerge. For instance, politicians/policymakers may be motivated to act in every possible sphere merely to increase their own power and thus do so for purely egotistical reasons, which could lead to conflict or political instability.

Governance also includes the effectiveness of governmental delivery of quality of public services (the third dimension). It entails the design and execution of policies imbued with a commitment to serve the people. This lends itself to the quality of governmental regulations (fourth dimension) in relation to the policies that should regulate and encourage the growth of the private sector. In order to maintain sustainable operations, the application of rules and regulations (the fifth dimension) is of paramount importance in maintaining the rule of law, with a view to ensuring both law and order and greater social equity. It highlights the sixth dimension as to the significance of measures pertaining to the controlling of corruption, the prevention of inappropriate usage of power, particularly that which is predisposed against the people's voice undermining political rights.

It is possible to presume that, in democratic societies-- where there is democratic governance--people exercise their political rights to impact public policy and thereby address public concerns. On the other hand, in authoritarian regimes, freedom is at stake in that powerful individuals control everything at their disposal to maximize their benefits by consolidating their power. In democratic regimes, politicians compete to hold public office through elections (the voice of the people). Nonetheless, it is possible to suggest that there can be some level of conflict, which can emanate from the competition. It is possible to "compare and contrast patterns of political conflict and competition in both democratic and authoritarian regimes (O’Neil and Share, 2010, p. 13)." Where there is competition, there 
could be greater aspiration to hold power to maximize individual benefit. Hughes (2012) affirms that the ambition of an individual can lead outside the collective realm to exploit personal gain. Thus, it can be argued that politicians may be motivated to act in every possible sphere merely to increase their own power and thus do so for purely egotistical reasons. Thus, the more there is an egoistic tendency in existence, the greater the prevalence of unchecked power that typically characterizes authoritarian regimes. This fosters a breeding ground for further corruption, and an almost total lack of respect for rule of law, which is against the principle of fair ruling.

In authoritarian regimes, power is concentrated in the hands of those few influential individuals who are accustomed to undermining the wishes and needs of the masses. Conversely, it is presumed that in democratic countries, power is devolved based on structured checks and balances. For instance, the existence of three branches of government (the legislative, judiciary and executive) — shared governing powers---in the U.S. makes it virtually less probable for the tendency towards egotism to produce an authoritarian rule (Fiorina, M., et al. 2011; Kraft, M. E., and Furlong, S. R., 2015). It is known that elected officials, including the President, can only hold public offices for their designated terms. In addition to this, elected officials are constrained from making any decision beyond their constitutional mandate (Robertson, D., 2012; Muir, W., 2012). And yet, the investigator acknowledges that elections at times may be used towards fulfilling the egoistic tendencies of elected officials. Nonetheless, the political and constitutional arrangement is designed to limit power based on popular participation exercised through political rights, such as voting, which ensures that the voice of the people is heard. In other words, the people's voice is better served in democratic societies where human rights are respected.

This study argues that democratic governance-serving the people and safeguarding political rights---by its very nature preserves fundamental human rights. As posted on the website of the United Nations (UN), the Universal Declaration of Human Rights (UDHR) emphasizes the importance of rights associated with anything that empowers citizens to enjoy civil benefits. This embraces the right to enjoy decent standard of living that includes the right to safety scheme during measures of unemployment. Such rights have been protected under UDHR (Article 25, 1). It is also specifically enshrined that everybody is entitled to inalienable rights such as political freedom, and right of assembly. Article 2 of the declaration states: "Everyone has the right to freedom of opinion and expression; this right includes freedom to hold opinions without interference and to seek, receive and impart information and ideas through any media and regardless of frontiers (Accessed on July 27, 2016)." In line with this, the African Charter on Democracy, Elections, and Governance (ACDEG), requires African countries to respect human rights through the promotion of good governance and accountability. As posted on the website of the African Union (AU), the Charter (Article 4, 1) affirms that: "State Parties shall commit themselves to promote democracy, the principle of the rule of law and human rights. (Last accessed on January 23, 2017)."

As the signatories of UDHR, and ACDEG, African governments are mandated to clear any roadblock which could stifle the voice of citizens from being heard. Anything conducted against the will of the people is considered a violation of human rights. In other words, 
listening to the voice of the people by protecting political rights inherently promotes human rights, which are universally recognized and acknowledged so essential that all citizens may have the opportunity to enjoy life in a meaningful manner. Roper and Barria (2009) reiterate that "no research area is better situated to address theoretical, empirical, and policy-relevant issues than human rights." Accordingly, this article argues that when political rights/the voice of the people respected, there can be human rights protection ensuring democratic governance. The impact of the identified governance indicators on political rights/the voice of the people will be determined corresponding the 32 African countries based on their common denominators (UDHR, and ACDEG). All of the countries under study are the signatories of these human rights tools. The premise is that the governance principles enshrined in all legislation in principle should limit the power and authority of political leaders, challenge authoritarianism, and so lead to the preservation of human rights. When this happens, it is possible to promote the respect for the voice of people maintaining accountability.

\section{Authoritarian Regimes: Lack of Level Playing Field}

Following the change in the global political order such as the end of the Cold War, the necessity for multi-party systems and democratic principles was widely echoed across the political spectrum, discouraging the remaining practitioners of authoritarianism (Levitsky and Way, 2010; Ottaway, 2003). Levitsky and Way (2010) point out that the downfall of the Soviet Union brought about a great challenge to authoritarian regimes. This resulted in the collapse of single-party systems and military dictatorships, but the transitions have not all brought democracy in their wake; rather, the rights to assembly and speech have been fictitiously promoted. "In much of Africa and the former Soviet Union, and in parts of Eastern Europe, Asia, and the Americas, new regimes combined electoral competition with varying degrees of authoritarianism (Levitsky and Way, 2010, p.3).” Opposing political groups have been given a chance to participate in the political process, but to a limited degree. Electoral competition has given rise to unbalanced political platforms favoring the reelection of incumbents through the control of the mass media, the squandering of public treasuries, and similar abuses. Levitsky and Way regard this as competitive authoritarianism; the opposition parties are merely competing without being given the opportunity of playing on a level playing field. In this regard, Diamond (2016) points out that many elections have been contested in Africa. He elucidates, "As has been the case in Nigeria - and Ethiopia, the Gambia, Kenya, Uganda, and Zimbabwe, among others - many of these elections have been brutally fought and outrageously rigged (p.254)."

Ottaway (2003) acknowledges incumbents' abuse of power and electoral competition coupled with simulated support for democracy and refers to a semi-authoritarianism which has created an ambiguous system. There are regimes which can be classified as neither democratic nor authoritarian. They are indefinite in that they entertain liberal democracy rhetorically, and establish some institutions that on the face of it promote democracy and the protection of civil liberties, while nevertheless maintaining intolerant or authoritarian methods. Ostensibly, they appear democratic in order to gain recognition and legitimacy, while avoiding political unpopularity by tolerating minimal political opposition. Ottaway indicates that there have been many semi-authoritarian regimes in various parts of the world including sub-Saharan 
Africa. According to her description, the consolidation of democratic systems has not been easy in countries that have undergone political transitions since the beginning of the 1990s. She attributes this to obstacles associated with undemocratic traditions, socioeconomic problems and ethnic or religious clashes. These multifaceted issues have also been obstacles to economic development, which in turn could affect the democratization process in African countries.

According to Levitsky and Way, since African countries have been dependent on external aid, they remain subject to influence from Western countries in one form or another. Countries such as the U.S. have had the tendency to link aid to democratic reform. Thus, the number of African countries with single party rule has been on the decrease. Similarly, Cheeseman (2015) argues that some African countries, due to problems such as instability, cannot uphold a transition to democracy without outside assistance; they are, in fact, democratically dependent. For instance, there is a tendency to expect donors to cover the expenses for electoral personnel, ballot documents, and the relevant logistics required during elections. He mentions some countries where their transitions needed external support: "...countries such as Angola, the DRC [Democratic Republic of Congo], Liberia, and Sierra Leone...unable to sustain the process of democratization without external support (p. 12)." Furthermore, he argues that the success of liberalization in Africa seems to be dependent upon the will of political elites since they possess dominant power. However, it must be clear that the question of democracy is not a ration to be apportioned by the will of political leaders. It is first and foremost a matter of human rights that citizens should enjoy through democratic governance. Akin to human rights concerns acknowledged in UDHR, the UN further emphasizes political rights in its International Convention on Economic, Social and Cultural Rights. It clarifies: “... the ideal of free human beings enjoying civil and political freedom and freedom from fear and want can only be achieved if conditions are created whereby everyone may enjoy his civil and political rights (Last visited September 24, 2017)." The interest of the people can only be fulfilled when there is commitment on the part of leaders who claim popular representation and when there is a genuine transformation that is commensurate with political rights. Of course, for this to happen the promotion of the level playing field is important to safeguard broad participation and ensure the representation of all citizens from all walks of life. This may be difficult to bring about within a short period of time where repression has been the norm, but without hearing widespread political opinion, it is scarcely possible to conceive of the promotion of human rights. Despite the difficulties, however, the democratization process is capable of eventually bringing about the voice of the people being heard and respected, even though the resistance of those holding power is hindering the pace of the democratization process. Authoritarianism is challenged, and in return challenging those who promote the preservation of political freedom and human rights.

\section{Democratization and Human Rights (U.S. Influence)}

The dictum of democratization and the respect for human rights resonate across the board. "There has been a decline in political inequalities due to the increase in suffrage democracy around the world over the last century, which is substantial despite variations and setbacks (Walby, 2009, p. 344)." As indicated above, authoritarianism is challenged, but it persists 
contrary to the democratic values of the Western world. Ottawa (2008), consistent with her ideas mentioned above, points out that authoritarian regimes do not publicly reject the demands of Western countries. Yet, they advocate for democracy merely as a form of appeasement while at the same time adhering to an authoritarian rule consisting of a mixture of positive and negative characteristics. This mixed stance has resulted in semi-authoritarian regimes. Nonetheless, in countries where semi-authoritarian regimes exist, there have been considerable improvements as compared to their previous totalitarian political ideologies. Presenting them as political hybrids, Ottawa notes that while these regimes promote multiparty democracy this does not translate in practice to a truly democratic system. Authoritarian regimes tend to resort to all possible measures in order to preserve power, including subverting of elections in the favor of incumbents. This is a great challenge towards partnering Western countries' democratic rule, such as the U.S. policy, which is virtually based on the promotion of the public interest. Ottawa (2008) states that: "From the point of view policy makers in the United States and other democratic countries, the most immediate challenge posed by semi-authoritarian regime is a policy one (Ottawa, 2008, p.10)." For instance, how can the U.S. provide democratic assistance to semi-authoritarian regimes? Apparently, the U.S has its own model of how to gauge the transitions to democracy.

The U.S. Department of State (DOS) has posted on its website that: "Democracy and respect for human rights have long been central components of U.S. foreign policy." (Last visited on September 24, 2017)." Appreciating its own political values, the U.S. is working in partnership with African countries strongly supportive of democratic principles. As described on the website of the United States Agency for International development (USAID), the U.S. with its partnership model is working with the sub-Saharan African countries in several key areas such as health, economic growth, and human rights. The USAID states that it works in collaboration by: "Supporting democracy, human rights, and good governance to help governments fight corruption, expand space for civil society, help citizens choose their leadership and strengthen the trend toward democratization in Africa (Accessed on November 1, 2016)." The point is that when there is democratic governance, and thus human rights, there is also a political stability which may be in the interest of the national security of the U.S. As the subject of human rights is about the people, it is part of the calculus of U.S. foreign policy in determining whether a country is democratic or not. DOS publishes annually the human rights records of governments around the world. According to DOS' publicly accessible archives, many of the regimes of sub-Saharan African countries do not provide a level playing field, which fact discourages citizens' voluntary participation in the political process. Even South Africa, the symbol of coexistence and tolerance, has faced some challenges that undermine democratic governance. "In South Africa today decency, politeness, and respect for the views of others appear to be on the wane (Gumede, 2012: p. 113)." The DOS records show that generally a degree of tolerance and respect for human rights exist in only a few countries (in, for example, Benin and Botswana). Consequently, any government action imposed against the will of the people demonstrates the existence of human rights violations committed by regimes in question. Following the ratification of UDHR, and ACDEG, it is expected that African governments are expected to promote democratic governance, which directs public institutions toward promoting citizen's participation in the 
political arena, establishes free and fair elections, freedom of assembly and access to uncensored media channels.

The condition of human rights is linked to the role that an individual might play in the community. In executing the expected normative role, an individual's political rights are protected when the rule of law reigns, and when democratic governance is in existence. This study argues that lack of political rights downplays popular participation, thereby smothering the voice of citizens, which may in certain circumstances be too weak to influence policy formulation with respect to their needs. When political rights are protected, the voice of the people can be heard, and thus human rights are respected, which signifies compliance with the principle of governance. Hence, the area of investigation is of paramount importance, and the focus of the study is on the sub-Saharan African countries. The five World Bank governance dimensions (indicators) identified herein have been utilized as independent variables, because the description of governance includes significant socio-economic factors. These factors include political stability; governments' commitment to frame and implement feasible policies encouraging economic development; and law enforcement as well as efforts to eliminate corruption.

In order to capture the impact of the economic dimension adequately, per capita GDP and unemployment rates obtained from the World Bank databases have also been used as independent variables. The dependent variable is the voice of the people/political rights, which is represented by the World Bank's voice and accountability measure corresponding to the 32 African countries during the course of 13 years (2002 to 2014). The premise is that when the voice of the people/political rights are respected, citizens can influence public policy warranting accountability, as well as cherishing the status of human rights. Hence, the overarching theme emphasizes that the limited existence of democracy and the copiousness of human right abuses can obstruct democratic governance in Africa. In other words, the voice of the people/political rights are affected by determinants of governance that have been further elucidated in the following hypothesis.

\section{Hypothesis and Objective of the Study}

The hypothesis is that there is a relationship between the dependent variable--political rights (the voice of the people)--in the 32 sub-Sharan African countries and the determinants of governance during the period from 2002 to 2014. The objective of the study is, therefore, to determine whether the voice of the people (political rights) has been impacted by the identified determinants of governance. These determinants have been listed as independent variables in Table 1. Further, the status of human rights and accountability will be determined together with the voice of the people. The presumption is that human rights and accountability are enhanced when there is a respect for the voice of the people. Hence, the hypothesis is based on the association between the dependent and the independent variables, which have been identified herein. The time period from 2002 to 2014 has been determined because of the availability of the data with the identified variables corresponding the African countries under study. Further, the data has been collected from one source (the World Bank). This has facilitated the compilation and assembly of the required data and the proper 
preparation of the dataset essential for the study.

\section{Methodology and Data}

\subsection{Data}

All the data comes from the World Bank websites (Last accessed on January 9, 2017). The data sources have been duly acknowledged and indicated in Table 1. They are publicly accessible for anybody interested to replicate this study. Focusing on political rights (the voice of the people), the study adopts the data available on the websites of the World Bank utilizing the voice and accountability measure as the dependent variable. As defined and explained above, voice and accountability/political rights signify citizens' ability to choose their government; and thus, their capability to influence public policy.

Hence, the investigator has used a number of variables, which have been adopted from the World Bank corresponding 32 sub-Saharan Africa countries. The countries are: Angola, Benin, Botswana, Burundi, Cameroon, Central African Republic, Chad, Congo Republic, Côte d'Ivoire, Democratic Republic of Congo, Equatorial Guinea, Ethiopia, Gabon, Gambia, Ghana, Guinea, Guine-Bissau, Kenya, Liberia, Malawi, Mali, Mozambique, Niger, Rwanda, Senegal, Sera Leone, South Africa, Tanzania, Togo, Uganda, Zambia, and Zimbabwe.

\subsection{The Model}

The data adopted from the World Bank databases aggregated on a time series scheme; and adequate dataset has been prepared to run the required regression computation. In this study, therefore, the dependent variable, one trend variable as well as seven independent variables have been computed all together to yield results based on their interactions. Since the dependent variable (voice/accountability) can be affected by different socioeconomic factors, seven independent variables (including per capita GDP and unemployment rates) have been utilized. The independent variables are: political stability, government effectiveness, and regulatory quality, rule of law, control of corruption, per capita GDP, and unemployment rates corresponding the identified countries during the course of 2002 to 2014. Year (as a trend variable) has been included in the statistical computation. The variables assembled in the regression equation have been identified with their corresponding sources in table 1 as follows.

In order to determine the statistical significance, based on the interaction of the identified variables, the linear regression model has been utilized. Linear regression helps to measure the estimation of the association between variables (Montgomery, Peck, and Vinig; 2012; Kim and Timm, 2007). Accordingly, the following formula has been utilized to run the regression: $Y=\beta 0+\beta 1 *$ Polistab $+\beta 2 *$ GovEffect $+\beta 3 *$ RegulatoryQ $+\beta 4 *$ RuleLaw $+\beta 5^{*}$ ConCorr $+\beta 6^{*}$ PCGDP $+\beta 7^{*}$ UnempRate $+\beta 8^{*}$ Year+error. 
Table 1 Variables and Identification

\begin{tabular}{|c|c|c|c|}
\hline \# & Variable & Identification & Source \\
\hline 1 & PoliStab & $\begin{array}{l}\text { political } \\
\text { stability/absence } \\
\text { of violence }\end{array}$ & $\begin{array}{l}\text { The World Bank, } \\
\text { at http://data.worldbank.org/data-catalog/worldwide- } \\
\text { governance-indicators }\end{array}$ \\
\hline 2 & GovEffect & $\begin{array}{l}\text { government } \\
\text { effectiveness in } \\
\text { the provision of } \\
\text { adequate service, } \\
\text { as well as design } \\
\text { and execution of } \\
\text { public policy }\end{array}$ & $\begin{array}{l}\text { The World Bank, } \\
\text { at http://data.worldbank.org/data-catalog/worldwide- } \\
\text { governance-indicators }\end{array}$ \\
\hline 3 & RegulatoryQ & $\begin{array}{l}\text { feasible policies } \\
\text { to encourage and } \\
\text { regulate private } \\
\text { sector }\end{array}$ & $\begin{array}{l}\text { The World Bank, } \\
\text { at http://data.worldbank.org/data-catalog/worldwide- } \\
\text { governance-indicators }\end{array}$ \\
\hline 4 & Rulelaw & $\begin{array}{l}\text { ensuring law and } \\
\text { order }\end{array}$ & $\begin{array}{l}\text { The World Bank, } \\
\text { at http://data.worldbank.org/data-catalog/worldwide- } \\
\text { governance-indicators }\end{array}$ \\
\hline 5 & ConCorr & $\begin{array}{l}\text { control of } \\
\text { corruption }\end{array}$ & $\begin{array}{l}\text { The World Bank, } \\
\text { at http://data.worldbank.org/data-catalog/worldwide- } \\
\text { governance-indicators }\end{array}$ \\
\hline 6 & PCGDP & per capita GDP & $\begin{array}{l}\text { The World Bank, } \\
\text { at http://data.worldbank.org/indicator/NY. } \\
\text { GDP.PCAP.PP.CD }\end{array}$ \\
\hline 7 & UnempRate & $\begin{array}{l}\text { Unemployment } \\
\text { Rate }\end{array}$ & $\begin{array}{l}\text { The World Bank at } \\
\text { http://data.worldbank.org/indicator/SL.UEM.TOTL.ZS?end } \\
=2006 \& \text { locations=AF\&start=1991 }\end{array}$ \\
\hline 8 & $\begin{array}{l}\text { VoiceA } \\
\text { (dependent } \\
\text { variable) }\end{array}$ & $\begin{array}{l}\text { political } \\
\text { rights/voice and } \\
\text { accountability }\end{array}$ & $\begin{array}{l}\text { The World Bank, at } \\
\text { http://data.worldbank.org/data-catalog/worldwide- } \\
\text { governance-indicators }\end{array}$ \\
\hline
\end{tabular}

In the model, political rights as a dependent variable $(\mathrm{Y})$ have been determined by the trend variable and the other seven independent variables identified in table 1 . The results, based on the linear regression procedure, have displayed statistical significance.

\section{Results and Analysis}

The SPSS computational technique was applied in order that the regression would proceed smoothly once the investigator successfully entered the dependent and independent variables into the system. Consequently, the results of the statistical computation have been adequate yielding meaningful p-values. The required statistical results have been displayed in Table 2 in order to determine statistical significance. The value of the standard errors (depicted in Table 2--column 3) corresponding each variable are quite adequate, signifying that the model is demonstrably reliable and valid. Further, the results shown in Table 2 (column 6) yielded meaningful $\mathrm{p}$ values corresponding to the trend variable as well as the seven independent variables. In order to obtain a clearer picture of the outcome of the study, the statistical results have been displayed in Table 2 below. 
Table 2. Panel Regression: Political Rights/VoiceA

Coefficientsa

\begin{tabular}{|c|c|c|c|c|c|}
\hline \multirow[t]{2}{*}{ Model } & \multicolumn{2}{|c|}{ Unstandardized Coefficients } & Standardized & \multirow[t]{2}{*}{$\mathrm{t}$} & \multirow[t]{2}{*}{ Sig. } \\
\hline & B & Std. Error & Beta & & \\
\hline (Constant) & -8.208 & 10.653 & ---- & -.770 & .442 \\
\hline PoliStab & .155 & .037 & .191 & 4.193 & .000 \\
\hline GovEffect & .193 & .091 & .158 & 2.114 & .035 \\
\hline RegulatoryQ & .367 & .083 & .313 & 4.437 & .000 \\
\hline RuleLaw & .326 & .106 & .274 & 3.073 & .002 \\
\hline ConCorr & -.113 & .078 & -.090 & -1.443 & .150 \\
\hline PCGDP & $-4.260 \mathrm{E}-5$ & .000 & -.261 & -7.823 & .000 \\
\hline UnemRate & .011 & .004 & .099 & 2.883 & .004 \\
\hline Year & .004 & .005 & .023 & .772 & .441 \\
\hline
\end{tabular}

Dependent Variable: VoiceA

$\mathrm{N}=390$

As can be seen above, the first category of the results portrays that the $\mathrm{p}$ values (less than the alpha level of .05) analogous to six independent variables corresponding to the dependent variable have signified six noticeable relationships. On the other hand, the statistical results regarding one independent variable, and trend variable in association with the dependent variable have generated insignificant relationships, because they are greater than the alpha level. Hence, focusing on the first set of variables, there is a strong relationship between political rights - the voice of people and accountability-- (VoiceA) and level of political stability (PoliStab). This is affirmed through the statistical significance corresponding to the preceding two variables at $\mathrm{p}$ equals .000. In other words, the level of political instability has affected the extent of political rights, which translates into the existence of less respect for political rights. One can, therefore, argue that the consistent political instability in the sub-Saharan African countries has resulted in the prevalence of less respect for political rights/the voice of the people. Therefore, this has resulted in a lower level of political rights, which has been deficient in addressing the governance interest of the people of these countries.

The relationship regarding the second set of variables, the voice of the people and government effectiveness in quality service delivery, measured at $\mathrm{p}$ equals to .035 , shows statistical significance. What this means is that the government sector's contribution has been less than the level desired to ensure the voice of the people/political rights. Failure in not addressing quality service delivery is equivalent to non-fulfilment of the benefits or demands of the public. In other words, it contradicts the presumption that political rights are the tools needed to attain the civil benefits that citizens are entitled to. Thus, the statistical result has led to the uncomplimentary conclusion that political rights have not been favored because of a lack of provision of delivery of quality service. As indicated in the literature review, the leaders have been preoccupied with protecting themselves from threats that challenge their power. What this indicates is that when it comes to the allocation of budgets, scant attention is given to adequate service delivery. The budget allocation strategy focuses on anything that 
would promote the continuity of rule of the regimes. In other words, governments reassure their own interests at the expense of the benefits of the people. They tend to undermine statehood values bolstering their propensity to focus on maximizing their interests against the principles of democratic governance. Thus, it may be imprudent to expect that African regimes inimical to the priority of citizens' benefits would simultaneously respect the voice of the people.

Likewise, there is a statistical significance (RegilatoryQ, p equals to .00) concerning the regulatory capacity of governments of the sub-Saharan African countries in formulating and implementing sound policies. This can simply mean that the governments' effort to encourage the private sector has been minimal. In other words, the less support given to the private sector, the less political rights and thus the less adequate governance approach would be followed. The statistical inference appears quite logical, because the information obtained through the literature review shows that the governments would tend to do anything possible to remain incumbents during every election season. It may be inappropriate to expect sound policy formulation from regimes which would ferociously contest for the permanency of their rules. This shows the lack of governance principles, which signify the voice of the people to determine the fate of a leader to remain in office. It is also appropriate to argue that the absence of democratic principles would result in the lack of sound policy formulation, which would address the public interest. What this means is the regimes authorities cannot be checked; any effort exerted to uphold the values of cherishing accountability would have been undermined.

The association between the rule of law and political rights is so significant (at $\mathrm{p}$ equals to .002). Given the human rights violations exhibited in most of the countries under study, the statistical significance apparently has revealed the actual state of affairs. This is even interesting because, based on the reviewed literature, the application of relevant laws concerning political rights most of the time has not been practical. For instance, it appears that the governments might have encouraged elections to be free and democratic by applying the rule of law superficially for short period of time (during elections season) to appease stakeholders such as the international community. Hence, consistent with what the literature has presented, it is very likely that political rights have been compromised in these countries. Thus, there is a strong likelihood that systematic election rigging has occurred behind the scenes with the undetected counting of an overwhelming number of the ballots in favor of incumbents. Such a practice would stifle the voice of the people making public policy formulation difficult to entertain the needs or demands of citizens. This would be an outright rejection of the principles of good governance.

When it comes to the association between corruption and political rights, a statistical insignificance ( $p$ equals to .150) has been observed. Based on statistical inference, it may not be possible to argue, that the degree of corruption has been greatly extensive in affecting political rights, and/or the voice of the people in the countries under study. Nonetheless, given the information collected via the literature review, the statistical inference attached to this result should not be interpreted while making the normal inferences. In other words, most of the leaderships of these countries of the region have been known for corruption. In fact, the 
statistical result ( $\mathrm{p}$ at .002) in the study corresponding the RuleLaw variable also presents the inference regarding the absence of respect for existing laws in these countries. It is valid for the study to assert that there would be instances of governmental practices in contradiction with administrative traditions that can ensure democratic governance. Consequently, it can be argued that the governance style in these countries is seriously flawed, which could utterly taint the illegitimacy of the regimes.

As to the impact of the economic conditions regarding the voice of the people in these countries, noticeable statistical significance has been obtained. As far as the two economic variables (unemployment and less productivity (less standard of living) associated with the voice of the people are concerned, two different relationships have been observed. Thus, productivity/standard of living as quantified through its proxy measure, per capita GDP (PCGDP) is part of the computation and a result has been obtained (at $\mathrm{p}$ equals to .000). What this means is that the level of PCGDP affects the political rights/the voice of the people in the sub-Saharan African countries. It can be argued that, as compared to wealthy countries such as the U.S., the voice of the people has been suppressed because of less productivity/less standard of living or because of a reduced amount of individual prosperity. This lends itself to a focus on the achievement of peoples' economic prosperity through employment has not been realized sufficiently. The inference, therefore, emphasizes less standard of living/ less level of prosperity, which is in contravention with what is enshrined under UDHR (Article 25, 1) regarding civil benefits that citizens should enjoy. In other words, the lack of necessities important to lead decent life hampered the capacity of citizens to become active participants to influence policy outcomes. Further, related to UDHR (Article 25, 1), the statistical significance ( $\mathrm{p}$ equals to .004) corresponding to the unemployment rate shows that the voice of the people or political rights have been impacted due to the prevalence of joblessness.

It can be argued that the inability of fulfilling the necessary provisions to lead life could negatively affect the bargaining power essential to gain political rights. Overall, it is appropriate to conclude that the voice of African people is not respected, and thus their political rights were in jeopardy during the 13 years of the study (between 2002 and 2014). It is possible to argue that on the count of six governance indicators, the voice of the people/political rights have been jeopardized in the region under study threatening the underlying principles enshrined in the two human rights instruments (UDHR and ACDEG). It is, therefore, possible to argue that the status of human rights will likely to remain hampered. When it comes to the relationship between the voice of the people/political rights (the dependent variable) and the trend variable, statistical insignificance (.441) has been observed. This inference shows that unless there is some change, as time progresses, in factors that can enhance the capacity of citizens, for instance, with a better standard of living, or based on an increase in income, gaining political rights would be unattainable. Thus, the uncomplimentary trend in matters that influence public policy in the sub-Saharan African countries is unlikely to change in favor of the voice of the people/political rights in a relatively near future. 


\section{Summary and Conclusion}

In light of the reviewed literature, particularly related to the international and regional human rights instruments (UDHR and ACDEG), the concepts of democratic governance, and human rights, the study has confirmed that the voice of the people/political rights have generally been undermined in sub-Saharan Africa. It is possible to assert that democratic governance has been absent or unstable and the rule of law has been lacking. According to the corresponding statistical inferences, it can also be determined that related economic factors such as high unemployment and less per capita GDP, which translates into less productivity or less standard of living (less income), has made the populace less powerful in political arena. Consequently, the voice of the people or political rights have not garnered significant respect, meaning that human rights violations have remained rampant. The incidence of allowing the public participation in the decision-making process has been minimal, undermining the principle that the government is accountable to the people. It can be argued that lack of accountability impeded public participation in matters that shape public policy in sub-Saharan African countries during the period from 2002 to 2014 . Hence, the opportunities for corruption could remain widespread and government operations could be seriously misguided due to maladministration.

Concurring with the literature, the study has presented the threatened status of democratic governance negatively affecting political rights of the people in the sub-Saharan Africa countries. The study has presented substantive information, which can serve to focus the attention of all stakeholders in exerting a concerted effort to influence these countries to promote democratic governance and be accountable to the people they govern. In other words, democratic nations are responsible to re-evaluate their partnerships, commensurate with their political values, in order to safeguard the status of human rights. It would be unethical to fulfil just the demands of the leaders who strive to maximize their benefits which reflects egoistic tendency and authoritarianism. The U.S. influence in the democratization process has been particularly noticeable, since it is strategically partnering with countries espousing the principles of good governance. Its interests can be maintained on a sustainable basis when the voice of the people is respected. Thus, it is important for the U.S. government to stand with the people of these countries, but not with the regimes. The United Nations, as a global governing entity, is entrusted with the responsibility to monitor and take timely measures against member countries, which perpetrate human rights' violations. If all concerned work together on the principles of respecting the voice of the people, political rights can gradually obtain a worthy level of respect, and thereby enabling accountability to prevail. Accordingly, democratic governance can guide the operations of governments towards improving political life on the continent. Human rights, therefore, become an increasingly important consideration throughout the region and an issue that will be increasingly difficult to avoid. If there is commitment, sub-Saharan Africa can experience transformation towards democratic governance. In tandem, arbitrary government domination will diminish and fair and popular administration principles be adopted thus facilitating a forum for citizens to be empowered and influence the formulation and implementation of public policy.

The investigator would like to acknowledge that the study has encountered a limitation in that 
it has precluded a few countries of sub-Saharan Africa due to the lack of data. However, the focus of this article is on democratic governance related to the principles of two human rights instruments (UDHR and ACDEG) to which all the countries under study are signatories. Thus, the article has been prepared based on these common denominators. Since the investigator has made certain the availability of pertinent data of comparable countries around the world, future focus in this area regarding comparative investigation looks feasible.

\section{References}

African Charter on Democracy, Elections and Governance, at https://www.au.int/web/sites/default/files/treaties/7790-file-african_charter_on_democracy_el ections_and_governance.pdf

Bevir, M. (2010). Democratic Governance. Princeton: Princeton University. https://doi.org/10.1515/9781400836857

Clawson, R., \& Oxley, Z. (2013). Public Opinion: Democratic Ideals, Democratic Practice. Los Angeles: CQ Press.

Diamond, L. (2016). In Search of Democracy. New York: Routledge.

Dye, T. (2008). Understanding Public Policy. Upper Saddle River: Pearson Prentice Hall.

Fiorina, M., Peterson, P., Johnson, B., \& Mayer, W. (2011). The New American Democracy. New York: Pearson Education Inc.

Freedom House. (2013). Freedom in the World 2013: Democratic Breakthroughs in the Balance. http://www.freedomhouse.org/report/freedom-world/freedom-world-2013.

Green, D., \& Luehrmann, L. (2007), Comparative Politics of the Third World. Boulder: Lynne Rienner Publishers, Inc.

Gumede, W. (2012). Restless Nation: Making Sense of Troubled Times. Cape Town: NB Publishers.

Hislope, R., \& Mughan, A. (2012). Introduction to Comparative Politics: The State and Its Challenges. New York: Cambridge University Press. https://doi.org/10.1017/CBO9781139015530

Hughes, O. (2012). Public Management and Administration. New York: Palgrave Macmillan. https://doi.org/10.1007/978-1-137-00305-8

Kim, K., \& Tim, N. (2007). Univariate and Multivariate General Linear Models: Theory and Application with SAS. New York: Chapman \& Hall/CRC.

Kraft, M. E., \& Furlong, S. R. (2015). Public Policy: Politics, Analysis, and Alternatives. Washington, DC: CQ Press.

Lee, T., \& Odugebemi, S. (2011). 'How Can Citizens Be Helped to Hold Their Governments Accountable?' In Accountability through Public Opinion: From Inertia to Public Action. Washington D.C.: The World Bank. https://doi.org/10.1596/9780821385050_CH28 
Levitsky, S., \& Way, L. (2010). Competitive Authoritarianism: Hybrid Regimes After the

Cold War. New York: Cambridge University Press. https://doi.org/10.1017/CBO9780511781353

Massey, A., \& Johnston, K. (2015). The International Handbook of Public Administration and Governance. Northampton: Edward Elgar publishing. https://doi.org/10.4337/9781781954492

Metelits, C., \& Matti, S. (2015). Democratic Contestation o the Margins: Regimes in Small Africa Countries. Lanham: Lexington Books.

Montgomery, D., Peck, E., \& Vining, G. (2012). Introduction to Linear Regression Analysis. Hoboken (NY): John Wiley \& Sons, Inc.

Morlino, L. (2012). Changes for Democracy: Actors, Structures, Processes. New York: Oxford University Press.

Muir, W. (2012). Freedom in America. Washington D.C.: CQ Press. https://doi.org/10.4135/9781483349503

Nick, C. (2015). Democracy in Africa: Success, Failures, and the Struggle for Political Reform. New York: Cambridge University Press.

O’Neil, P., Fields, K., \& Share, D. (2010). Cases in Comparative Politics. New York: W.W. Norton \& Company.

Ottaway, M. (2003). Democracy Challenged: The Rise of Semi-Authoritarianism.Washington, D.C.: The Brooking Institution Press.

Rawls, J. (1999) The Law of Peoples. Cambridge: Harvard University Press.

Ricker, W. (2014). Human Rights without Political Rights. In Hum Rights Rev, 15, 369-390. https://doi.org/10.1007/s12142-014-0341-3

Robertson, D. (2012). Federalism and the Making of America. New York: Routledge.

Roper, S., \& Barria, L. (2009). Political Science Perspectives on Human Rights. In Human Rights Review, 10, 305-308. https://doi.org/10.1007/s12142-009-0125-3

The World Bank, at http://info.worldbank.org/governance/wgi/index.aspx\#home

United Nations, International Convention on Economic, Social and Cultural Rights, at http://www.hrweb.org/legal/escr.html.

United Nations, Universal Declaration of Human Rights, at http://www.un.org/en/universal-declaration-human-rights/.

United States Agency for International Development, at https://www.usaid.gov/where-we-work/africa.

Walby, S. (2009). Globalization \& Inequalities: Complexity and Contested Modernity's. Thousand Oaks: SAGE Publications Inc. 


\section{Copyright Disclaimer}

Copyright for this article is retained by the author(s), with first publication rights granted to the journal.

This is an open-access article distributed under the terms and conditions of the Creative Commons Attribution license (http://creativecommons.org/licenses/by/4.0/). 